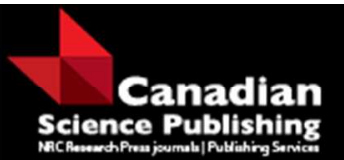

Canadian Journal of Forest Research

Revue canadienne de recherche forestière

\title{
Multiple developmental pathways for range-margin Pinus banksiana forests
}

\begin{tabular}{|r|l|}
\hline Journal: & Canadian Journal of Forest Research \\
\hline Manuscript ID & cjfr-2015-0321.R1 \\
\hline Manuscript Type: & Article \\
\hline Date Submitted by the Author: & 05-Nov-2015 \\
\hline Complete List of Authors: & $\begin{array}{l}\text { Gill, Kyle; University of Minnesota, Dept. of Forest Resources } \\
\text { DAmato, Anthony; Rubenstein School of Environment and Natural } \\
\text { Resources, University of Vermont } \\
\text { Fraver, Shawn; University of Maine, School of Forest Resources }\end{array}$ \\
\hline Keyword: & $\begin{array}{l}\text { Dendrochronology, Early-successional forest, Jack pine, Marginal } \\
\text { population, Range of variability }\end{array}$ \\
\hline
\end{tabular}

\section{SCHOLARONE ${ }^{\text {m }}$ \\ Manuscripts}


2 Multiple developmental pathways for range-margin Pinus banksiana forests 3

$6{ }^{1}$ Department of Forest Resources, University of Minnesota, St. Paul, Minnesota, USA 55108

$7 \quad{ }^{2}$ Rubenstein School of Environment and Natural Resources, University of Vermont, Burlington, 8 Vermont, USA 05405

$9 \quad{ }^{3}$ School of Forest Resources, University of Maine, Orono, Maine, USA 04469

10

11 *Corresponding author; e-mail: gillx096@umn.edu (Phone: +1 612-624-3400; Fax: 612-625-

12 5212)

13

14 Keywords: Dendrochronology; early-successional forest; jack pine; marginal population; range

15 of variability 


\section{Abstract:}

18 Empirical knowledge of forest structure and development in early-successional and range-margin

19 populations is often lacking, limiting our ability to effectively model and manage these forests.

20 Such is the case for jack pine (Pinus banksiana) in central Minnesota, USA, where it reaches its

21 southwestern range limit. Our objective was to quantify this population's historical range of

22 variability of structural conditions and developmental pathways. We collected structural, spatial,

23 and dendrochronological data on 0.25 ha plots from ten jack pine-dominated sites that initiated

24 and developed outside of active management. Our results revealed a broad range of structural

25 characteristics and developmental pathways, including rapid and protracted recruitment windows

26 (5 - 50 years), with subsequent even- and uneven-aged structures, and random and clumped stem

27 spatial arrangements. As such, these mature, early-successional forests often displayed a degree

28 of complexity more typically associated with old-growth forests. Our findings suggest that this

29 population, like other southern range-margin populations with mostly non-serotinous cones,

30 historically followed a variety of stand development pathways, not solely the rapid-

31 establishment, even-aged pathway often attributed to this forest type. We suggest that even- and

32 uneven-aged silvicultural systems should be used to reflect this historical range of developmental

33 pathways and to increase resilience and adaptability. 


\section{Introduction}

Plant populations located at their geographic range margins tend to display atypical

39 species traits and population-level dynamics due to their proximity to sub-optimal abiotic

40 conditions and ecotonal community associations (Kawecki 2008). These marginal populations

41 represent the dynamic edges of a species' larger central population whose expansion or

42 contraction indicates range or elevation shifts. Conservation of marginal populations - including

43 their connectivity with central populations and their biologically diverse ecotone communities -

44 is seen as a way to maintain migratory and adaptive potential in the face of uncertain future

45 conditions (Lesica and Allendorf 1995). Given their unusual character, as well as their

46 vulnerability to change, there is a great need to document their historical variation and adaptive

47 potential to establish baselines for assessing long-term climate impacts and develop targets for

48 setting conservation priorities (Keane et al. 2009).

49 Currently, knowledge of the historical range of variability for range-margin populations

50 is limited because the focus has primarily been on non-marginal populations (e.g. Fraver and

51 Palik 2012). In forested settings, this focus has left key knowledge gaps regarding the variability

52 of structure and developmental pathways associated with these forests. In addition, the behavior

53 of these systems has rarely been included in forest dynamics and species distribution models,

54 despite the fact that they may be the first to face and respond to altered environmental stressors,

55 which limits the current predictive power of such models (Seidl et al. 2011). An understanding of

56 the range of variability in marginal populations would not only assist predictions of potential

57 future range distributions and variation, but provide the foundation for appropriate local adaptive

58 management (D'Amato et al. 2011) 
In a similar regard, the range of variability in early-successional forest developmental

60 pathways is often unknown, but is a topic that is now gaining increased attention (Swanson et al.

61 2011). Many early-successional forests are expected to develop along conventional even-aged

62 pathways with relatively homogeneous structure (e.g., spatial arrangement and age range) and

63 composition (Oliver and Larson 1996). However, given the complex nature of forest systems and

64 their dynamic response to disturbance events (Puettmann et al. 2009), alternative developmental

65 pathways that include more structural complexity should also be expected (Donato et al. 2012).

66 These pathways may include longer periods of herbaceous vegetation and shrub dominance

67 along with protracted tree recruitment windows (period when most recruitment occurs) and time

68 until canopy closure (Nyland 1998). Although different pathways may converge towards similar

69 mature forest conditions (Kashian et al. 2005), understanding the range of variability in potential

70 pathways can have important modeling and management implications.

71 Jack pine (Pinus banksiana Lamb.) is an abundant, early-successional tree species of the

72 boreal forest biome that has been studied across much of its natural range, which extends from

73 Canada's Northwest Territories to the Maritime Provinces and south to the Great Lakes region of

74 the USA. A southern range-margin population displaying atypical traits, such as non-serotinous

75 cones (Schoenike 1976), and community associations with tallgrass prairie speies (Aaseng et al.

76 2003) exists along the prairie-forest ecotone in north-central North America. Neither the

77 structural characteristics nor the associated developmental pathways of this marginal population

78 have been thoroughly documented. Other southern range-margin populations have been

79 investigated in Indiana (Chun and Choi 2012), Michigan (Abrams et al. 1985) and Maine (Barton

80 and Grenier 2008), USA, but no work has examined a full set of structural characteristics,

81 including establishment, development, and spatial patterns. Such data are critical for 
82 understanding regional and range-wide variation and potential future conditions for this forest

83 type. In addition, this topic has timely and important regional management implications because

84 both natural and artificial regeneration difficulties in jack pine stands are contributing to a

85 reduction of this forest type. These difficulties may be caused by incongruity between the

86 historical dynamics and contemporary use of even-aged management, the removal of fire from a

87 fire-prone system (e.g., Platt et al. 1988), high levels of herbivory (White 2012), or shifts in

88 suitable climatic conditions (Zhu et al. 2012).

89 In the current study, we investigated the natural range of variability of structure and

90 development in early-successional jack pine-dominated forests near their range margin in north-

91 central Minnesota to document reference conditions for monitoring future climate impacts and to

92 inform regional adaptive management (D'Amato et al. 2011). Specifically, we aimed to 1)

93 quantify the natural range of variability of stand structure in representative stands; and 2)

94 characterize historical stand development patterns that have shaped contemporary, natural jack

95 pine forests in this region. Our results demonstrate varying levels of structural complexity and

96 suggest a range of early development pathways for jack pine forests. These can be reflected in

97 the region through the use of both even- and uneven-aged silvicultural systems, which could also

98 promote stand- and landscape-level resilience.

99 Methods

100 Study area

101 Our study area (Fig. 1) is located within the Northern Minnesota Drift and Lake Plains

102 (MDL) ecological subsection of the Laurentian Mixed Forest Province (Aaseng et al. 2003). The

103 MDL has complex surface geology due to a patchy distribution of glacial deposits such as

104 outwash, lake and till plains, moraines, and drumlin fields (Aaseng et al. 2003). The cold- 
105 temperate continental climate in the region is characterized by short cool summers and long cold

106 winters with periods of temperature extremes in both seasons. Using monthly PRISM climate

107 data for each study site (www.prism.oregonstate.edu) and the time period 1913 - 2012, the mean

108 total annual precipitation, over $80 \%$ of which fell between April and October, was $632 \mathrm{~mm}$ (SD

$109=102 \mathrm{~mm}$ ), the mean minimum winter (December - January) temperature was $-19{ }^{\circ} \mathrm{C}(\mathrm{SD}=4$

$110{ }^{\circ} \mathrm{C}$ ) and the mean maximum summer (June - August) temperature was $25^{\circ} \mathrm{C}\left(\mathrm{SD}=2{ }^{\circ} \mathrm{C}\right)$.

\section{Site selection}

112 We focused our site selection on locating mature to decadent jack pine-dominated sites

113 older than the recommended commercial forestry rotation lengths (40-70 years; Burns and

114 Honkala 1990) that had regenerated and developed outside of active management. In the attempt

115 to ensure natural stand origin and development, we sought sites with little or no evidence of past

116 management such as cut stumps, uniform (plantation-like) tree spacing, furrows, or logging

117 roads. To capture the oldest sites possible and avoid the influence of known periods of heavy

118 management, we sought out sites that initiated prior to 1950, included jack pine snags, and

119 contained a variety of tree crown and diameter classes. These characteristics also provided the

120 possibility of locating multi-aged jack pine systems that are expected to exist along the southern

121 range-margin (e.g., Barton and Grenier 2008). Potential sites were provided by the Minnesota

122 Department of Natural Resources, along with input from other area professionals. Together,

123 these sources identified 128 potential sites that were first screened for management activity via

124 historical aerial photographs (1939-2012). From this pool, 76 were inspected on the ground.

125 Ten sites ultimately met our criteria and were selected for sampling (Fig. 1, Table 1).

126 Field and laboratory methods 
Within each site, one $50 \times 50 \mathrm{~m}$ study plot was randomly or systematically established

128 along cardinal directions during 2012 (Midge Lake sites) or 2013 (all other sites). For larger

129 sites, a point was randomly selected in a GIS and established as plot center. For two relatively

130 small sites ( $\sim \mathrm{ha})$, we placed plot center in the geographic center to avoid edge bias. Within

131 each plot all trees $\geq 10 \mathrm{~cm}$ diameter at breast height $(\mathrm{DBH}, 1.37 \mathrm{~m})$ were sampled. Each tree was

132 given a unique number and sampled for species, $\mathrm{DBH}$, crown class (based on Kraft classification

133 system; Oliver and Larson 1996), mortality class (living or snag), and location (within-plot $x$ -

134 and $y$-coordinates). Saplings, defined as any tree species taller than breast height and $<10 \mathrm{~cm}$

$135 \mathrm{DBH}$, were tallied by species in three $5 \times 50 \mathrm{~m}$ within-plot transects.

136 The volume of downed woody debris (DWD) was estimated using the line-intercept

137 method (Van Wagner 1968) to further quantify stand structural conditions. DWD $\geq 10 \mathrm{~cm}$ in

138 diameter at line-intersection point was sampled along eight equiangular line-intercept transects

139 radiating from plot center, for a total of $241 \mathrm{~m}$ of transect per plot. Each piece was sampled for

140 species (or genus when precluded by advanced decay), diameter at intersection, and decay class

141 (Sollins 1982). DWD volume per hectare was calculated as per Van Wagner (1968) and reduced

142 to account for collapse of decay class IV and V pieces (Fraver et al. 2013).

143 To characterize age structures, development patterns, and disturbance histories, increment

144 cores were collected at $30 \mathrm{~cm}$ above the forest floor from all living and, when possible, standing

145 dead trees (snags). In the laboratory, increment cores were affixed to wooden mounts and sanded

146 using progressively finer grits (up to 800 grit) in order to clearly reveal ring anatomy. If the core

147 had not passed directly through the pith, the number of missing rings to pith was visually

148 estimated (Applequist 1958); cores estimated to be greater than 10 years from pith were excluded

149 from age-related analyses. The pith year, or adjusted pith year, was taken as the year of 
150 recruitment and used to represent the age of the individual. A Velmex sliding-stage micrometer

151 (Velmex Inc., Bloomfield, NY) was used to measure annual growth rings to the nearest 0.001

$152 \mathrm{~mm}$. All cores were cross-dated visually (Yamaguchi 1991) and statistically confirmed with

153 COFECHA (Lamont-Doherty Earth Observatory, www.ldeo.columbia.edu). Cores from snags

154 were cross-dated using marker years from associated site-level live-tree chronologies and

155 statistically confirmed with COFECHA. Stand-wide growth patterns and disturbance events were

156 assessed by creating standardized growth chronologies for jack pine from each site; additional

157 chronologies were developed for any additional species at sites where the species had an

158 importance value (IV; [relative basal area + relative density] / 2; Curtis and McIntosh 1951) $\geq$

$15925 \%$. To this end, each tree-ring series was fit with a horizontal line through the mean ring width,

160 and annual ring-widths were divided by fitted values (i.e. mean ring width) to produce a unit-less

161 index (Fritts 1976). These indexed series were then averaged to arrive at a standardized, indexed

162 time series that maintains stand-wide growth trends related to disturbance (Veblen et al. 1991).

163 Chronologies were developed in ARSTAN v44h3 (Lamont-Doherty Earth Observatory,

164 www.ldeo.columbia.edu) and only interpreted for portions where sample size included ten or

165 more series. To further refine site disturbance history, cores were collected from on-site trees that

166 displayed fire scars, following the methods of Barrett and Arno (1988).

167 Analyses

168 Age distributions and jack pine recruitment windows were developed to characterize

169 stand establishment and development. For age distributions, individuals at each site were

170 grouped by five-year age-class intervals. Jack pine recruitment windows were calculated at each

171 site to quantify the time it took for a majority of jack pine trees to recruit into the site and to

172 determine if they met standard criteria for being even-aged (tree age ranges around $20 \%$ of 
173 rotation). Because the recommended jack pine rotation ages are between 40 - 70 years (Burns

174 and Honkala 1990), we used 15 years as the maximum even-aged recruitment window length.

175 Recruitment windows were calculated using the interpercentile range spanning the $5^{\text {th }}$ through

$17695^{\text {th }}$ percentiles of year of recruitment. The middle $90 \%$ was assumed to represent a majority of

177 individuals while excluding potential outliers.

178 To further elucidate stand establishment and development patterns, the spatial

179 arrangement of jack pine stems at each plot was assessed using the pairwise correlation function

180 (Stoyan and Stoyan 1994). Analyses of the univariate spatial distributions of all jack pine stems

181 (living and standing dead pooled) were conducted for each plot using the spatstat package

182 (Baddeley and Turner 2005) in R (www.r-project.org) to test against null hypotheses of complete

183 spatial randomness (CSR) using isotropic edge correction and pointwise significance bands $(\alpha=$

184 0.05) produced by 499 Monte Carlo simulations. The pooled group was used because it was

185 thought to provide the most complete picture of patterns from early establishment through

186 maturity (our interest) prior to decadence. However, we recognize that true number of

187 individuals is likely underestimated because of potential early mortality and loss of some stems.

188 Analyses conducted with solely living jack pine stems revealed comparable results (not shown)

189 to those using all stems; however, we focus on the pooled group given this better represents

190 stand development prior to decadence. Additionally, four sites that had protracted and continuous

191 jack pine recruitment and sufficient sample depth were further analyzed to assess potential

192 differences in the spatial patterns of trees through time. The same process as above was used to

193 analyze spatial patterns of two age groups ('older' and 'younger') at each site. Using only

194 individuals that recruited during the calculated recruitment window, groups were separated at the

195 median tree age (older $>$ median $\geq$ younger) to provide relatively balanced samples. The spatial 
196 arrangement of all individuals included in these latter analyses was first assessed at each site to

197 confirm that the sample was representative of the population (results not shown).

198 Results

199 Composition and structure

200 Jack pines were the predominant species and structural components across the study sites,

201 but other species were present and sometimes abundant. Jack pine importance values (IV) ranged

202 from $27-89 \%($ mean $\pm S E=50 \pm 6 \%$ ) across sites (Table 2$)$. Red pine (Pinus resinosa) had

203 lower and more variable IVs across sites, ranging from $0-72 \%$ (mean $\pm S E=25 \pm 7 \%$ ). Paper

204 birch (Betula papyrifera) was absent or a minor component at most sites, but at Bladder Lake it

205 constituted a greater portion of the stand basal area than living jack pine (Table 3; but see basal

206 area of jack pine snags). Total live tree densities ranged from 376 - 904 trees ha ${ }^{-1}$ (species

207 pooled) and from $128-696$ trees $^{-1} \mathrm{~h}^{-1}$ for living jack pine (Table 2). The basal area of living trees

208 ranged from $16.4-32.5 \mathrm{~m}^{2} \mathrm{ha}^{-1}$ (species pooled) and from $7.1-19.0 \mathrm{~m}^{2} \mathrm{ha}^{-1}$ for living jack pine

209 (Table 3). Stand-level diameter distributions (Fig. 2; species pooled) varied in shape across sites

210 from unimodal (Midge Lake West), bimodal (Nimrod Range), to negative exponential (Midge

211 Lake East). The DBH distributions of jack pine (Fig. 2, black bars) were primarily unimodal; this

212 shape was wider (e.g., Lake George), or absent (Midge Lake East), in stands with protracted

213 recruitment windows (see below). Mean jack pine diameter at each site ranged from $18.2-28.5$

$214 \mathrm{~cm}($ mean $\pm S E=23.5 \pm 1 \mathrm{~cm})$.

215 Jack pine was most abundant in upper canopy layers (dominant and co-dominant) and

216 decreased in abundance in lower layers (intermediate and suppressed). Red pine, paper birch,

217 Populus species, and Quercus species were the primary species in the intermediate and

218 suppressed layers, but composition varied between sites (Table 3). Total sapling density (species 
219 pooled) ranged from 560 - 2187 stems ha $^{-1}$ (Table 2). Oak saplings, 84\% of which were red oaks

220 (Quercus rubra), were the most abundant sapling species group. Very few jack pines were found

221 in the sapling layer (Table 2).

222 Standing and downed deadwood was abundant at all sites but the causes of mortality

223 were not explicitly determined. Jack pine snags $(N=670)$ occurred nearly as often as living jack

224 pine $(N=674)$; snags of other species were uncommon $(N=15)$. The snag basal area was greater

225 than that of living jack pine at three of ten sites (Table 3; BL, RC, and WL); however, snag

226 diameters tended to be smaller than those of living jack pines at all sites (Fig. 2). The mean

227 diameter of jack pine snags per site ranged from $13.9-23.3 \mathrm{~cm}($ mean $\pm S E=19.2 \pm 1.0 \mathrm{~cm})$.

228 The total DWD volume per site ranged from $18.8-125.6 \mathrm{~m}^{3} \mathrm{ha}^{-1}$ (Table 2), of which $43-99 \%$

229 (mean $\pm S E=83.2 \pm 5.3 \%$ ) was jack pine. The majority of DWD at many sites was in decay

230 classes II and III, yet distribution among decay classes varied (Fig. A1).

231 Age distributions and stand development

232 Tree age distributions including all species showed uneven-aged structures at all sites

233 (Fig. 3, bars). Sites tended to have one primary pulse of jack pine recruitment, often protracted,

234 with recruitment of additional jack pine and other species prior, during, and/or after this period.

235 Most sites displayed varied, but usually low, levels of non-jack pine recruitment concurrent with

236 the primary jack pine cohort (e.g., Straight River). At several sites, small cohorts of red pine

237 recruited 30-80 years prior to the initiation of a majority of other individuals (e.g., Nimrod Range

238 and Roy Creek). These sites also tended to have additional red pine recruitment concurrent with,

239 or slightly delayed from, the primary jack pine pulse. At Bladder Lake and Lake George, cohorts

240 of paper birch and red pine, respectively, occurred after the establishment of most jack pines, and 
241 these species constituted a greater live stem importance relative to jack pine at the time of

242 sampling (Table 2; see Disturbance effects on stand development and succession).

243 Jack pine age distributions (Fig. 3, black bars) and recruitment windows (Fig. 4) indicate

244 both even-aged and uneven-aged structures but typically display one primary pulse with varying

245 levels of additional jack pine recruitment surrounding the pulse. The duration of jack pine

246 recruitment windows for four sites that met even-aged criteria ranged from five years (Fig. 4,

247 NR) up to 15 years (Fig. 4, BL). The other six sites had uneven-aged jack pine with protracted

248 recruitment windows (up to 50 years; Fig. 4, ME) and age structures that followed three primary

249 patterns (Fig. 3). At Straight River, two distinct cohorts were separated by just under a decade of

250 no recruitment. At Midge Lake East, Midge Lake West, and Wolf Lake, varying levels of low to

251 nearly continuous recruitment either preceded or followed a primary cohort that had a five- to

252 ten-year window. A similar trend was observed at Lyons Forest and Lake George but with

253 primary cohorts spanning $10-15 \mathrm{yr}$.

254 No clear relationship between age structures and disturbance events was observed.

255 Evidence of past fires was rare and only once showed a direct influence on age structures (Fig.

256 3). In particular, at Nimrod Range the earliest cohort of red pine recruited shortly after an autumn

2571894 or spring 1895 fire (Fig. 3). These trees later (ca. 1945) displayed an abrupt growth

258 increase (Fig. 3, Nimrod Range, grey line) concurrent with the recruitment of the even-aged jack

259 pine cohort. However, the cause of this event was unclear. The fires documented at Lake George

260 and Roy Creek do not appear to have fostered recruitment (Fig. 3). Some sites showed evidence

261 of a July 2012 regional windstorm, as demonstrated by the high percentage of recent DWD at

262 many sites (Fig. A1). Additionally, abrupt periods of near zero growth in jack pines (see below) 
263 may suggest past intermediate disturbances by wind or insects that could be contributing to jack

264 pine mortality, although there was no observed linkage with jack pine recruitment.

265 Site-level mean jack pine growth (Fig. 3, black lines) generally followed a gradually

266 declining pattern, yet growth releases and irregular and parabolic growth patterns were also

267 observed. Most notably, jack pine individuals at Midge Lake West that recruited prior to 1967,

268 roughly $35 \%$ of total recruitment, showed a period of up to 20 years of suppressed growth

269 followed by an abrupt and sustained growth increase beginning around 1967 (Fig. 3). Concurrent

270 with this release, a new jack pine cohort recruited, individuals of which followed gradually

271 declining growth patterns. Mean growth curves for jack pine also showed years with sharply

272 reduced ring width or nearly zero growth (Fig. 3, black lines, e.g., 1979 at Bladder Lake and

273 Lyons Forest); however, other important species did not show concurrent growth reductions (Fig.

274 3; grey lines). In fact, these species tended to maintain or increase in growth as stand-wide jack

275 pine growth declined later in stand development (Fig. 3; e.g., Roy Creek, grey line).

\section{Spatial patterning}

277 Analyses of the spatial arrangement of jack pine stems demonstrated significant

278 deviations from complete spatial randomness (CSR) at half of the sites where tree age was not

279 considered and all four sites where tree age was considered. When different from CSR, stems

280 (living stems plus snags) were most often clumped. This was the case at various distances,

281 primarily between 2 - 8 m (Fig. 5; Nimrod Range, Lake George, Beaver Dam, Straight River and

282 Midge Lake West); Nimrod Range also indicated clumping at larger distances (Fig. 5). Both the

283 older and younger groups of trees at sites with protracted recruitment demonstrated significant

284 clumping. This was evident at many distances in the older age group at all four sites (Fig. 6) and

285 primarily between $2-8 \mathrm{~m}$ in the younger group at three of four sites (Fig 6; Lyons Forest, Lake 
286 George, and Midge Lake East). At these three sites the stems of the age groups were generally

287 segregated spatially (Fig. 7); however, groups at Midge Lake West, where the spatial

288 arrangements were rarely different from CSR, were generally more interspersed (Fig. 7).

\section{Discussion}

290 Collectively, our results indicate that jack pine-dominated systems in this region can be

291 structurally complex and may follow a wide range of stand development pathways to maturity,

292 not only the conventional single-cohort pathway typically expected (Gauthier et al. 1993). The

293 abundance or heterogeneity of structural metrics employed (i.e. tree age, spatial arrangement,

294 deadwood) suggest levels of structural complexity at some sites more often associated with late-

295 successional forests (Donato et al. 2012; Franklin et al. 2002) and further underscore the

296 diversity of post-disturbance stand development pathways for early-successional systems

297 (Nyland 1998; Swanson et al. 2011). Moreover, the ability of these systems to progress along

298 various developmental and successional pathways suggests the potential for inherent range-

299 margin system adaptability and resiliency and argues for the use of an equally diverse range of

300 management approaches (D'Amato et al. 2011; Puettmann 2011).

\section{Stand composition, structure, and development}

302 Our results show the current abundance and stature of jack pine and associated tree

303 species to be within the ranges of earlier descriptions of these communities in this region (e.g.,

304 Spurr 1954). Basal areas and tree densities were on the low end of, or sometimes below, ranges

305 reported from other naturally regenerated jack pine stands (e.g., Schoenike 1976) and

306 recommended in management guides (e.g. Archibald and Bowling 1995), further highlighting the

307 range-wide variation in jack pine systems (Schoenike 1976). This finding, together with the

308 clumped spatial distributions, reflect the heterogeneous and interrupted canopies observed at 
309 some sites (Fig. 8). The variation in live-tree size distributions and canopy structures also reflects

310 the diversity of age structures observed.

311 Early-successional forests adapted to develop following stand-replacing disturbance are

312 generally expected to display strongly even-aged populations, short recruitment windows, and

313 high initial stand densities (Oliver and Larson 1996). Several sites we examined displayed such

314 characteristics (Nimrod Range, Beaver Dam, and Roy Creek), although the remnant red pine

315 cohorts suggest that stand-initiating disturbances were not lethal to all individuals in the pre-

316 disturbance forest. However, the jack pine age structures more often observed in our study -

317 even where initial stand conditions appear to have been relatively open - indicated protracted

318 recruitment windows (up to 50 years) that are much longer than typically expected. Protracted

319 stand initiation stages have elsewhere been observed in Douglas-fir (Pseudotsuga menziesii)

320 forests of the Pacific Northwest, USA (Freund et al. 2014) and montane lodgepole pine (Pinus

321 contorta var. latifolia) forests (Kashian et al. 2005; Nyland 1998). These findings have called

322 into question previous notions of ubiquitous rapid, post-disturbance recruitment for these species

323 and suggests that a post-disturbance open period with spatially heterogeneous seedling

324 establishment might be a typical early-successional condition (Swanson et al. 2011).

325 The protracted recruitment found in our study may have been caused by low initial stand

326 densities and subsequent infilling of new recruits (Nyland 1998). Although density-dependent,

327 age-related, and agent-based mortality likely reduced stand densities over time, the observed age

328 and spatial structures, as well as rapid early growth rates (Fig. 3), suggest that stand conditions at

329 initiation were often open and densities were relatively low. These conditions have been shown

330 for this species after abandoned land-conversion attempts (Thomson 1943) and following high-

331 severity fires (Pinno et al. 2013). The observed heterogeneous spatial patterns of protracted 
332 recruitment suggests that soil and light conditions favorable for germination varied across space

333 and time. Presumably, precocious seed production and dispersal (as early as five to ten years;

334 Burns and Honkala 1990) and non-serotinous cones at maturity (Schoenike 1976) are expected to

335 have allowed for this spatially and temporally complex pathway (Nyland 1998). Similar

336 opportunistic and protracted recruitment related to open or low density canopy conditions,

337 moderate to low competition, and minimal intermediate disturbance has been observed in other

338 range-margin jack pine forests (e.g., Barton and Grenier 2008) as well as other early-

339 successional forests (e.g., Kashian et al. 2005)

340 Tree spatial arrangement and growth patterns also suggest that jack pine does not

341 necessarily require fully open conditions for establishment, however. Spatial patterns in several

342 stands revealed heterogeneous spatial patterns and clumping of stems recruited in sizeable gaps

343 between pre-established trees. This is best demonstrated in the younger group of recruitment at

344 Midge Lake East (Fig. 7, grey circles) and in the even-aged jack pines at Nimrod Range (Fig.

345 A2, circles). Clumping of conifers has been shown in numerous previous studies and attributed

346 to inter-species repulsion (Beland et al. 2003) or heterogeneous canopy conditions and microsite

347 availability following disturbances (Larson and Churchill 2012; Platt et al. 1988). Both of these

348 likely contributed to the complex spatial structures and establishment patterns observed in this

349 study. The 20 years of recruitment, supression, and eventual release of jack pines at Midge Lake

350 West - establishment and growth patterns which have rarely been observed for this species

351 (Copenheaver and Abrams 2003) - provides additional evidence of this species' unexpected

352 ability to establish and persist, through patchy and, potentially, suppressive conditions.

353 Disturbance effects on stand development and succession 
Fire is often put forth as the primary disturbance agent shaping the development of jack

355 pine stands (Gauthier et al. 1993) and its importance is generally manifest during stand initiation

356 (Pinno et al. 2013) due to the preparation of a mineral soil seedbed and release of seeds from

357 serotinous cones. Previous work documenting multi-cohort jack and red pine populations have

358 indicated that surface fires are important for recruiting additional cohorts over the course of stand

359 development (Bergeron and Brisson 1990; Fraver and Palik 2012; Gauthier et al. 1993), as is the

360 case for pines in other regions (e.g., Platt et al. 1988). We found little direct evidence linking the

361 observed even and uneven-aged establishment to fires, although physical records of surface fires

362 do not always occur or persist (Piha et al. 2013). But given the demonstrated positive link

363 between fire frequency and serotiny (Gauthier et al. 1996) the historical occurrence of surface

364 fires in the region can be inferred from the low levels of cone serotiny present (Schoenike 1976).

365 Additionally, age structures displaying clear cohort recruitment, rather than low levels of

366 extended recruitment, may be indicative of past surface fires. If so, the later cohorts at Straight

367 River and Wolf Lake (Figs. 3 \& 4) may have been generated by surface fires that left no physical

368 evidence other than age structures. However, the continuous protracted recruitment periods

369 observed (e.g., Midge Lake East, Fig. 3), are more likely related to heterogeneous low density

370 initial post-disturbance recruitment (Nyland 1998) combined with disturbance quiescence (sensu

371 Brown 2006) or, potentially, to insect or wind disturbances (Svoboda et al. 2010).

372 A variety of biotic and abiotic disturbance agents have affected the observed structural

373 conditions but their linkages with stand decadence are more clear than those of stand

374 establishment. Although our study sites were naturally regenerated, it is likely that logging

375 activities ca. 1900 - 1950 were influential. Historic photographs and rapid early growth in jack

376 pines at some sites indicate that many initiated under relatively open growing conditions. Though 
377 we cannot determine the cause of these conditions, the broader regional land-use history suggests

378 they may have initiated through logging and fire disturbance, the combination of which was

379 prevalent in the region into the 1920s before fire suppression efforts became effective (Spurr

380 1954), or land-conversion attempts (Thomson 1943). Insect and wind disturbances appear to be

381 having the greatest influence on current stand structure through the creation of snags and DWD.

382 Jack pine budworm (Choristoneura pinus) outbreaks are known to have recurred in the study

383 region (2012 Forest Health Annual Report, www.dnr.state.mn.edu), and synchronous decreases

384 in growth (Fig. 3, e.g. Lyons Forest) along with the high abundance of snags suggest that many

385 of our sites were affected. As well, strong evidence of wind-related mortality, in the form up

386 uprooted trees and splintered stem snaps, was also present at several sites. These and other

387 agents of intermediate disturbance that do little to create mineral soil seedbed and light

388 conditions conducive to pine regeneration appear instead to primarily alter stand structure in a

389 way that promotes succession (Gilliam and Platt 1999).

390 Many of the jack pine stands we sampled were succeeding away from dominance by this

391 species. Historically, red and white (Pinus strobus) pine would be expected to increase in

392 dominance through succession (Aaseng et al. 2003). Results from several stands (e.g. Lake

393 George and Beaver Dam) support this successional trajectory. However, results from other

394 stands (e.g. Bladder Lake and Straight River) suggest that fire-suppression has promoted

395 succession towards dominance by deciduous tree and shrub species. Similar trajectories have

396 been observed following fire exclusion in other fire-adapted systems (Nowacki and Abrams

397 2008). Given the current challenges from competing hardwood species, high levels of herbivory,

398 and fire suppression, pine regeneration and establishment will only occur in these systems

399 through targeted management actions that retain seed availability, create favorable light and 
400 seedbed conditions, and protect seedlings from browse damage (White 2012). Prescribed fire has

401 been one effective approach for promoting historical size, age and spatial structures in pyrogenic

402 forests that face similar biotic and abiotic pressures (e.g., Gilliam and Platt 1999).

403 Management implications and conclusions

404 The variation in compositional and structural complexity observed across our sites

405 augments findings from jack pine forests in Indiana (Chun and Choi 2012) and Maine (Barton

406 and Grenier 2008), USA as well as in Ontario and Quebec, Canada (Gauthier et al. 1993). These

407 findings support the growing body of literature addressing the complexity of post-disturbance

408 developmental pathways - often the result of early open periods and spatially heterogeneous tree

409 establishment (Nyland 1998) - for systems historically believed to follow a simple, single-cohort

410 self-thinning trajectory. Other such systems include Pinus contorta in the western USA (e.g.,

411 Nyland 1998), Pseudotsuga menziesii communities in the Pacific Northwest, USA (Donato et al.

412 2012; Freund et al. 2014), and Pinus sylvestris forests in northern Europe (Kuuluvainen and

413 Aakala 2011). Conservation and promotion of these early-successional forests is critical, as their

414 role in larger ecosystem function has only recently been appreciated (Swanson et al. 2011). Non-

415 conventional management techniques may be required to meet these goals, particularly when the 416 systems also face novel conditions due to their range-margin proximity.

417 The range of structure and developmental patterns documented in this study suggests that 418 a variety of even- and uneven-aged silvicultural techniques can be ecologically justified to

419 restore, manage, and promote jack pine forests of varying complexities. Our results demonstrated 420 that a range of recruitment window lengths and initial seedling densities should be considered as 421 a normal part of the development processes (Kashian et al. 2005). They also suggest that seed 422 rain, whether from adjacent stands, on-site retention (Franklin et al. 2002), or precocious 
423 seedling maturity (Burns and Honkala 1990), can supplement initial tree densities over time

424 (Nyland 1998). Thus, it is important that post-harvest or post-disturbance regeneration not

425 necessarily be considered a failure if initial stocking goals are not immediately met (e.g. five

426 years). These early processes are likely to be actively or passively influenced by many factors

427 such as cone serotiny level and associated seed availability (Lamont et al. 1991), the abundance

428 and dispersion of suitable mineral soil seedbeds (Burns and Honkala 1990), presence and type of

429 herbaceous competition, and the degree to which herbivory is minimized. Both multi-aged

430 regeneration techniques (i.e., seed-tree with reserves and variable retention harvesting) and even-

431 aged systems (i.e. clearcutting and conventional seed-tree), along with intermediate treatments

432 (i.e. variable density thinning), should be used across the landscape. Using a range of techniques

433 will promote the historical diversity of conditions by allowing within- and among-stand

434 developmental diversity and complexity (Puettmann et al. 2009). Such a diverse management

435 approach is also thought to increase landscape-level adaptability and resilience (Puettmann

436 2011), which should be the preeminent management goal for range-margin forests.

\section{Acknowledgements}

438 Financial support was provided by the US DOI's Northeast Climate Science Center,

439 University of Minnesota Department of Forest Resources, and the Minnesota Department of

440 Natural Resources (MN DNR). We thank K. Kipfmueller and two anonymous reviewers for

441 helpful comments on earlier drafts of the manuscript; F. Falzone, M. Reinikainen and N. Jensen

442 and other members of the University of Minnesota Silviculture Lab Group for help in the field,

443 laboratory and/or with analyses; J. Almendinger, H. Tjader, K. Jacobson, M. Locke, B. Marty, E.

444 Rowe, C. Gronewold and others from the MN DNR for their insights and assistance in locating

445 study sites; and Zac and Bunny Dunlap for allowing their forest to be sampled (Wolf Lake). 


\section{Literature cited}

Aaseng, N.E., Almendinger, J.C., Rusterholz, K., Wovcha, D., and Klein, T.R. 2003. Field guide to the native plant communities of Minnesota: The Laurentian mixed forest province. Minnesota Dept. of Natural Resources, St. Paul, MN. Available from http://www.dnr.state.mn.us/ecs/.

Abrams, M.D., Sprugel, D.G., and Dickmann, D.I. 1985. Multiple successional pathways on recently disturbed jack pine sites in Michigan. Forest Ecology and Management 10(1-2): 31-48. doi: 10.1016/0378-1127(85)90012-x.

Archibald, D.J., and Bowling, C. 1995. Jack pine density management diagram for boreal Ontario. OMNR, Northeast and Northwest Science \& Technology.

Baddeley, A., and Turner, R. 2005. spatstat: An R package for analyzing spatial point patterns. Journal of Statistical Software 12(6): 1-42.

Barrett, S.W., and Arno, S.F. 1988. Increment-borer methods for determining fire history in coniferous forests. U.S. Dept. of Agriculture, U.S. Forest Service, Intermountain Research Station, Ogden, UT. Report: INT-244.

Barton, A.M., and Grenier, D.J. 2008. Dynamics of jack pine at the southern range boundary in downeast Maine. Canadian Journal of Forest Research 38(4): 733-743. doi: 10.1139/x07-176.

Beland, M., Lussier, J.M., Bergeron, Y., and Longpre, M.H. 2003. Structure, spatial distribution and competition in mixed jack pine (Pinus banksiana) stands on clay soils of eastern Canada. Annals of Forest Science 60(7): 609-617. doi: 10.1051/forest:2003053. 
Bergeron, Y., and Brisson, J. 1990. Fire regime in red pine stands at the northern limit of the species' range. Ecology 71(4): 1352-1364. doi: 10.2307/1938272.

Brown, P.M. 2006. Climate effects on fire regimes and tree recruitment in Black Hills ponderosa pine forests. Ecology 87(10): 2500-2510. doi: 10.1890/0012-9658(2006)87[2500:ceofra]2.0.co;2.

Burns, R.M., and Honkala, B.H. 1990. Silvics of North America. Volume 1, Conifers. U.S. Dept. of Agriculture, Forest Service, Washington D. C. Available from http://www.na.fs.fed.us/spfo/pubs/silvics_manual/table_of_contents.htm.

Chun, Y.M., and Choi, Y.D. 2012. Structure, species composition, and soil characteristics in a chronosequence of jack pine (Pinus banksiana Lamb.) stands on the southern shore of Lake Michigan. The American Midland Naturalist 168(2): 408-426. doi: 10.1674/0003-0031168.2.408.

Copenheaver, C.A., and Abrams, M.D. 2003. Dendroecology in young stands: case studies from jack pine in northern lower Michigan. Forest Ecology and Management 182(1-3): 247-257. doi: http://dx.doi.org/10.1016/S0378-1127(03)00049-5.

Cummins, J.F., and Grigal, D.F. 1980. Soils and land surfaces of Minnesota. Dept. of Soil, Water and Climate, University of Minnesota Agricultural Experiment Station.

Curtis, J.T., and McIntosh, R.P. 1951. An upland forest continuum in the prairie-forest border region of Wisconsin. Ecology 32(3): 476-496. doi: 10.2307/1931725. 
D'Amato, A.W., Bradford, J.B., Fraver, S., and Palik, B.J. 2011. Forest management for mitigation and adaptation to climate change: Insights from long-term silviculture experiments. Forest Ecology and Management 262(5): 803-816. doi:

http://dx.doi.org/10.1016/j.foreco.2011.05.014.

Donato, D.C., Campbell, J.L., and Franklin, J.F. 2012. Multiple successional pathways and precocity in forest development: Can some forests be born complex? Journal of Vegetation Science 23(3): 576-584. doi: 10.1111/j.1654-1103.2011.01362.x.

Franklin, J.F., Spies, T.A., Pelt, R.V., Carey, A.B., Thornburgh, D.A., Berg, D.R., Lindenmayer, D.B., Harmon, M.E., Keeton, W.S., Shaw, D.C., Bible, K., and Chen, J. 2002. Disturbances and structural development of natural forest ecosystems with silvicultural implications, using Douglas-fir forests as an example. Forest Ecology and Management 155(1-3): 399-423. doi: http://dx.doi.org/10.1016/S0378-1127(01)00575-8.

Fraver, S., Milo, A.M., Bradford, J.B., D'Amato, A.W., Kenefic, L., Palik, B.J., Woodall, C.W., and Brissette, J. 2013. Woody debris volume depletion through decay: implications for biomass and carbon accounting. Ecosystems 16(7): 1262-1272. doi: 10.1007/s10021-013-9682-z.

Fraver, S., and Palik, B.J. 2012. Stand and cohort structures of old-growth Pinus resinosadominated forests of northern Minnesota, USA. Journal of Vegetation Science 23(2): 249-259. doi: 10.1111/j.1654-1103.2011.01348.x. 
Freund, J.A., Franklin, J.F., Larson, A.J., and Lutz, J.A. 2014. Multi-decadal establishment for single-cohort Douglas-fir forests. Canadian Journal of Forest Research 44(9): 1068-1078. doi: 10.1139/cjfr-2013-0533.

Fritts, H.C. 1976. Tree rings and climate. Academic Press, London; New York.

Gauthier, S., Bergeron, Y., and Simon, J.-P. 1996. Effects of fire regime on the serotiny level of jack pine. Journal of Ecology 84(4): 539-548. doi: 10.2307/2261476.

Gauthier, S., Gagnon, J., and Bergeron, Y. 1993. Population age structure of Pinus banksiana at the southern edge of the Canadian boreal forest. Journal of Vegetation Science 4(6): 783-790. doi: $10.2307 / 3235615$.

Gilliam, F.S., and Platt, W.J. 1999. Effects of long-term fire exclusion on tree species composition and stand structure in an old-growth Pinus palustris (Longleaf pine) forest. Plant Ecol 140(1): 15-26. doi: 10.1023/a:1009776020438.

Kashian, D.M., Turner, M.G., Romme, W.H., and Lorimer, C.G. 2005. Variability and convergence in stand structural development on a fire-dominated subalpine landscape. Ecology 86(3): 643-654. doi: 10.1890/03-0828.

Kawecki, T.J. 2008. Adaptation to marginal habitats. Annual Review of Ecology Evolution and Systematics 39: 321-342. doi: 10.1146/annurev.ecolsys.38.091206.095622. 
Keane, R.E., Hessburg, P.F., Landres, P.B., and Swanson, F.J. 2009. The use of historical range and variability (HRV) in landscape management. Forest Ecology and Management 258(7): 1025 1037. doi: http://dx.doi.org/10.1016/j.foreco.2009.05.035.

Kuuluvainen, T., and Aakala, T. 2011. Natural forest dynamics in boreal Fennoscandia: A review and classification. Silva Fennica 45(5): 823-841. doi: 10.14214/sf.73.

Lamont, B.B., Lemaitre, D.C., Cowling, R.M., and Enright, N.J. 1991. Canopy seed storage in woody-plants. Bot. Rev. 57(4): 277-317. doi: 10.1007/bf02858770.

Larson, A.J., and Churchill, D. 2012. Tree spatial patterns in fire-frequent forests of western North America, including mechanisms of pattern formation and implications for designing fuel reduction and restoration treatments. Forest Ecology and Management 267: 74-92. doi: 10.1016/j.foreco.2011.11.038.

Lesica, P., and Allendorf, F.W. 1995. When are peripheral-populations valuable for conservation? Conservation Biology 9(4): 753-760. doi: 10.1046/j.1523-1739.1995.09040753.x.

Little, E.L. 1971. Atlas of United States trees: Conifers and important hardwoods. U. S. Department of Agriculture, Washington, D.C., WA.

Nowacki, G.J., and Abrams, M.D. 2008. The demise of fire and "mesophication" of forests in the eastern United States. BioScience 58(2): 123-138. doi: 10.1641/b580207.

Nyland, R.D. 1998. Patterns of lodgepole pine regeneration following the 1988 Yellowstone fires. Forest Ecology and Management 111(1): 23-33. doi: 10.1016/s0378-1127(98)00308-9. 
Oliver, C.D., and Larson, B.C. 1996. Forest stand dynamics. Wiley, New York.

Piha, A., Kuuluvainen, T., Lindberg, H., and Vanha-Majamaa, I. 2013. Can scar-based fire history reconstructions be biased? An experimental study in boreal Scots pine. Canadian Journal of Forest Research 43(7): 669-675. doi: 10.1139/cjfr-2012-0471.

Pinno, B.D., Errington, R.C., and Thompson, D.K. 2013. Young jack pine and high severity fire combine to create potentially expansive areas of understocked forest. Forest Ecology and Management 310: 517-522. doi: 10.1016/j.foreco.2013.08.055.

Platt, W.J., Evans, G.W., and Rathbun, S.L. 1988. The population dynamics of a long-lived conifer (Pinus palustris). The American Naturalist 131(4): 491 - 525. doi: 10.1086/284803.

Puettmann, K.J. 2011. Silvicultural challenges and options in the context of global change: "Simple" fixes and opportunities for new management approaches. Journal of Forestry 109(6): $321-331$.

Puettmann, K.J., Coates, K.D., and Messier, C.C. 2009. A critique of silviculture: Managing for complexity. Island Press, Washington DC.

Schoenike, R.E. 1976. Geographical variations in jack pine (Pinus banksiana). Agricultural Experiment Station, University of Minnesota. Tech. Bull. 304-1976.

Seidl, R., Fernandes, P.M., Fonseca, T.F., Gillet, F., Jönsson, A.M., Merganičová, K., Netherer, S., Arpaci, A., Bontemps, J.-D., Bugmann, H., González-Olabarria, J.R., Lasch, P., Meredieu, C., Moreira, F., Schelhaas, M.-J., and Mohren, F. 2011. Modelling natural disturbances in forest 
ecosystems: A review. Ecol. Model. 222(4): 903-924. doi:

http://dx.doi.org/10.1016/j.ecolmodel.2010.09.040.

Sollins, P. 1982. Input and decay of coarse woody debris in coniferous stands in western Oregon and Washington. Canadian Journal of Forest Research 12(1): 18-28. doi: 10.1139/x82-003.

Spurr, S.H. 1954. The forests of Itasca in the nineteenth century as related to fire. Ecology 35(1): 21-25. doi: 10.2307/1931399.

Stoyan, D., and Stoyan, H. 1994. Fractals, random shapes, and point fields: methods of geometrical statistics. John Wiley \& Sons, New York.

Svoboda, M., Fraver, S., Janda, P., Bače, R., and Zenáhlíková, J. 2010. Natural development and regeneration of a central European montane spruce forest. Forest Ecology and Management 260(5): 707-714. doi: http://dx.doi.org/10.1016/j.foreco.2010.05.027.

Swanson, M.E., Franklin, J.F., Beschta, R.L., Crisafulli, C.M., DellaSala, D.A., Hutto, R.L., Lindenmayer, D.B., and Swanson, F.J. 2011. The forgotten stage of forest succession: Earlysuccessional ecosystems on forest sites. Frontiers in Ecology and the Environment 9(2): 117-125. doi: $10.1890 / 090157$.

Thomson, J.W., Jr. 1943. Plant succession on abandoned fields in the central Wisconsin sand plain area. Bulletin of the Torrey Botanical Club 70(1): 34-41. doi: 10.2307/2481679.

Van Wagner, C.E. 1968. The line intersect method in forest fuel sampling. Forest Science 14(1): 20-26. 
Veblen, T.T., Hadley, K.S., Reid, M.S., and Rebertus, A.J. 1991. The response of subalpine forests to spruce beetle outbreak in Colorado. Ecology 72(1): 213-231. doi: 10.2307/1938916.

White, M.A. 2012. Long-term effects of deer browsing: Composition, structure and productivity in a northeastern Minnesota old-growth forest. Forest Ecology and Management 269(0): 222228. doi: http://dx.doi.org/10.1016/j.foreco.2011.12.043.

Yamaguchi, D.K. 1991. A simple method for cross-dating increment cores from living trees. Canadian Journal of Forest Research 21(3): 414-416. doi: 10.1139/x91-053.

Zhu, K., Woodall, C.W., and Clark, J.S. 2012. Failure to migrate: Lack of tree range expansion in response to climate change. Global Change Biology 18(3): 1042-1052. doi: 10.1111/j.13652486.2011.02571.x. 
Table 1. Site names, codes, and stand characteristics for the ten range-margin jack pine study sites.

\begin{tabular}{|c|c|c|c|c|c|}
\hline Site Name & $\begin{array}{l}\text { Site } \\
\text { Code }\end{array}$ & Native Plant Community $^{a}$ & Geomorphic Description $^{b}$ & Soil Texture $^{c}$ & $\begin{array}{l}\text { Stand Size } \\
\text { (ha) }\end{array}$ \\
\hline Beaver Dam & $\mathrm{BD}$ & Northern Dry-Sand Pine Woodland & Hillslopes on moraines & Coarse-loamy & 4 \\
\hline Bladder Lake & BL & Central Rich Dry Pine Woodland & Outwash plains & Sandy & 13 \\
\hline Lyons Forest & $\mathrm{LF}$ & Central Dry Pine Woodland & Outwash plains & Coarse-loamy & 40 \\
\hline Lake George & LG & Central Poor Dry Pine Woodland & $\begin{array}{l}\text { Flats on outwash plains, rises } \\
\text { on outwash plains }\end{array}$ & Sandy & 15 \\
\hline Midge Lake East & $\mathrm{ME}$ & Central Dry Pine Woodland & Outwash plains, valley trains & Sandy & 59 \\
\hline Midge Lake West & MW & Central Dry Pine Woodland & Outwash plains, valley trains & Sandy & 59 \\
\hline Nimrod Range & NR & Central Rich Dry Pine Woodland & Hillslopes on outwash plains & Sandy & 10 \\
\hline Roy Creek & $\mathrm{RC}$ & Central Rich Dry Pine Woodland & Hillslopes on outwash plains & Fine-loamy & 4 \\
\hline Straight River & SR & Central Rich Dry Pine Woodland & Hillslopes on moraines & Sandy & 28 \\
\hline Wolf Lake & WL & Central Rich Dry Pine Woodland & Hillslopes on outwash plains & Sandy & 31 \\
\hline
\end{tabular}

a. Aaseng (2003)

b. SSURGO (data downloaded from www.websoilsurvey.nrcs.usda.gov)

c. Cummins and Grigal (1980) 
Table 2. Structural characteristics of range-margin jack pine study stands including live tree density (trees ha ${ }^{-1}$ ) and importance value (IV), jack pine snag density, sapling density for jack pine (JP) and for all species (Total), and downed woody debris (DWD) volume. Jack pine had the highest live tree IV in a given plot, unless noted. See Table 1 for site codes.

\begin{tabular}{|c|c|c|c|c|c|c|c|}
\hline \multirow[b]{2}{*}{ Site } & \multirow{2}{*}{$\begin{array}{c}\begin{array}{c}\text { Live } \\
\text { trees }\end{array} \\
\text { trees ha }{ }^{-1}\end{array}$} & \multicolumn{2}{|c|}{$\begin{array}{c}\text { Jack Pine } \\
\text { Living }\end{array}$} & \multirow{2}{*}{$\begin{array}{l}\text { Jack Pine } \\
\text { Snags } \\
\text { trees ha }^{-1}\end{array}$} & \multicolumn{2}{|c|}{ Saplings } & \multirow{2}{*}{$\frac{\text { DWD }}{\mathrm{m}^{3} \mathrm{ha}^{-1}}$} \\
\hline & & trees $\mathrm{ha}^{-1}$ & IV \% & & $\mathrm{JP} \mathrm{ha}^{-1}$ & Total ha ${ }^{-1}$ & \\
\hline $\mathrm{BD}$ & 800 & 292 & 40.5 & 284 & . & 1253 & 72.3 \\
\hline $\mathrm{BL}$ & 528 & 128 & $32.3^{a}$ & 212 & . & 1573 & 67.2 \\
\hline LF & 516 & 348 & 64.8 & 196 & 27 & 987 & 13.9 \\
\hline LG & 904 & 232 & $27.3^{b}$ & 276 & . & 560 & 21.3 \\
\hline $\mathrm{ME}$ & 376 & 224 & 57.4 & 276 & 67 & 2187 & 29.9 \\
\hline MW & 780 & 696 & 89.1 & 308 & 13 & 1053 & 18.8 \\
\hline NR & 448 & 236 & $44.7^{c}$ & 208 & . & 1373 & 39.8 \\
\hline $\mathrm{RC}$ & 444 & 184 & 45.5 & 288 & . & 1227 & 125.6 \\
\hline SR & 408 & 144 & 47.2 & 168 & . & 1027 & 60.3 \\
\hline WL & 476 & 212 & 49.6 & 464 & . & 1147 & 54.6 \\
\hline Mean & 568 & 270 & 49.8 & 268 & 11 & 1239 & 50.4 \\
\hline$(S E)$ & $(59.3)$ & $(51.6)$ & $(5.6)$ & (26.4) & (6.8) & (135) & $(10.7)$ \\
\hline \multicolumn{8}{|c|}{ a. Betula papyrifera IV $=56.9 \%$} \\
\hline \multicolumn{8}{|c|}{ b. Pinus resinosa $\mathrm{IV}=72 \%$} \\
\hline c. P.r & nosa $\mathrm{IV}=$ & $5 \%$ & & & & & \\
\hline
\end{tabular}


Table 3. Live tree basal area $\left(\mathrm{m}^{2} \mathrm{ha}^{-1}\right)$ for each species or species group, plus standing dead jack pine trees (snags), by site. See Table 1 for site codes.

\begin{tabular}{|c|c|c|c|c|c|c|c|c|c|c|c|c|}
\hline & Species & $\mathrm{BD}$ & $\mathrm{BL}$ & LF & LG & $\mathrm{ME}$ & MW & NR & $\mathrm{RC}$ & SR & WL & Mean (SE) \\
\hline \multirow[t]{8}{*}{ Live Trees } & Pinus banksiana & 14.5 & 7.1 & 11.9 & 8.7 & 8.7 & 19.0 & 11.1 & 10.8 & 9.7 & 9.3 & $11.1(1.1)$ \\
\hline & Pinus resinosa & 11.5 & 0.0 & 6.5 & 21.3 & 5.3 & 1.1 & 18.1 & 6.9 & 0.9 & 1.8 & $7.4(2.4)$ \\
\hline & Betula papyrifera & 2.0 & 9.2 & 0.7 & 0.0 & 0.3 & 0.0 & 0.1 & 0.2 & 0.6 & 2.0 & $1.5(0.9)$ \\
\hline & Populus spp. ${ }^{a}$ & 4.1 & 0.6 & 0.0 & 0.0 & 0.0 & 0.0 & 0.3 & 2.2 & 2.4 & 3.0 & $1.3(0.5)$ \\
\hline & Quercus spp. ${ }^{b}$ & 0.0 & 0.6 & 0.0 & 0.0 & 0.8 & 0.2 & 0.6 & 0.7 & 1.9 & 0.3 & $0.5(0.2)$ \\
\hline & Other Conifers $^{c}$ & 0.5 & 0.0 & 0.0 & 0.2 & 0.6 & 1.0 & 0.0 & 0.5 & 0.0 & 0.5 & $0.3(0.1)$ \\
\hline & Other Deciduous $^{d}$ & 0.0 & 0.1 & 0.0 & 0.0 & 0.1 & 0.0 & 0.0 & 0.5 & 0.9 & 0.1 & $0.2(0.1)$ \\
\hline & Stand total & 32.5 & 17.5 & 19.1 & 30.2 & 15.8 & 21.4 & 30.1 & 21.8 & 16.4 & 17.0 & $22.2(2.0)$ \\
\hline Snags & Pinus banksiana & 9.9 & 9.4 & 4.9 & 5.5 & 8.7 & 5.0 & 6.2 & 12.5 & 6.9 & 15.2 & $8.4(1.1)$ \\
\hline \multicolumn{13}{|c|}{$a-P$. grandidentata and P. tremuloides } \\
\hline \multicolumn{13}{|c|}{$b-Q$. macrocarpa and $Q$. rubra } \\
\hline \multicolumn{13}{|c|}{ c-Abies balsamea, Picea glauca, Picea mariana, and Pinus strobus } \\
\hline \multicolumn{13}{|c|}{ d-Acer rubrum, Alnus incana, Prunus serotina, Fraxinus pennsylvanica, and Ulmus americana } \\
\hline
\end{tabular}




\section{Figure Legends}

Figure 1. Location of study area and sites within a southern range-margin jack pine (Pinus banksiana) population in north-central Minnesota, USA. Jack pine range (grey shading) is from Little (1971).

Figure 2. Diameter at breast height $(\mathrm{DBH})$ distributions of living trees $\left(n_{\text {living }}\right.$ listed below site name) and snags (inset) for ten range-margin jack pine sites $\left(N_{\text {living+snag }}=2105\right)$. Diameter classes are labeled by the minimum value of the $5 \mathrm{~cm}$ class range.

Figure 3. Age distributions (bars) and standardized radial growth indices (lines) for ten rangemargin jack pine sites. Ages are grouped into five-year classes. Triangles indicate fire-scar dates. Growth indices are shown for each site where $n \geq 10$ for jack pine (Pinus banksiana; black line) and, if criteria were met (see Methods), a second species (grey line); this species was most often red pine (P. resinosa) but was paper birch (Betula papyrifera) at Bladder Lake.

Figure 4. Jack pine recruitment windows at ten range-margin jack pine sites. Black dots represent recruitment of at least one individual in a given year at a given site. Recruitment windows (black-lined rectangle) mark the $5^{\text {th }}$ and $95^{\text {th }}$ percentiles of year of recruitment to enclose the middle $90 \%$ of recruited trees. The total window length (years) is listed in parentheses beside the site code (codes found in Table 1). The threshold for designating sites as even- or uneven-aged (above or below the grey line, respectively) was 15 years (see Methods). Year of recruitment at each site was standardized by its median year of recruitment for display. Figure 5. Spatial distribution of all living and snag jack pine trees (stems pooled) at each site as a function of distance $r$. The solid line displays the observed value $\left(\hat{g}_{o b s}\right)$ for a given distance, the dashed line the theoretical value ( $\left.g_{\text {theo }}\right)$ for complete spatial randomness (CSR), and the grey 
shaded areas are a 95\% significance band of CSR produced by 499 Monte Carlo simulations. Observed values above or below this band are indicative of clumping or uniformity, respectively. Figure 6. Spatial distribution as a function of distance $(r)$ of two age groups at four sites that had protracted and continuous recruitment. 'Older' and 'younger' age groups were separated at the median tree age (older $>$ median $\geq$ younger). For each, the solid line displays the observed value $\left(\hat{g}_{\text {obs }}\right)$ for a given distance, the dashed line the theoretical value $\left(g_{\text {theo }}\right)$ for complete spatial randomness (CSR), and the grey shaded area is a 95\% significance band of CSR produced by 499 Monte Carlo simulations. Observed values above or below this band are indicative of clumping, which is observed at many distances in both age groups, or uniformity, respectively. Figure 7. Jack pine tree locations for four sites that had protracted and continuous recruitment windows and sufficient sample sizes for spatial analyses by age group. For each site, jack pine trees are separated into older (black circles) and younger (light grey circles) age groups based upon the median tree age (older $>$ median $\geq$ younger). For display, icons are sized to reflect intrasite relative DBH; see Fig. 2 for actual DBH ranges at each site. See Fig. 6 for results of spatial pattern analyses.

Figure 8. Photo of the Pinus banksiana forest at the Lyons Forest study site showing an interrupted low density canopy, stem clumping (background left), and a range of diameter and canopy sizes in P. banksiana (three foreground stems, as well as others with scaly bark). Patchy understory clumps of Corylus americana (middle-ground right) are also evident on this site of medium moisture and nutrient quality. The jack pine recruitment window was 30 years. (Photo by K.G. Gill). 
Figure 1.

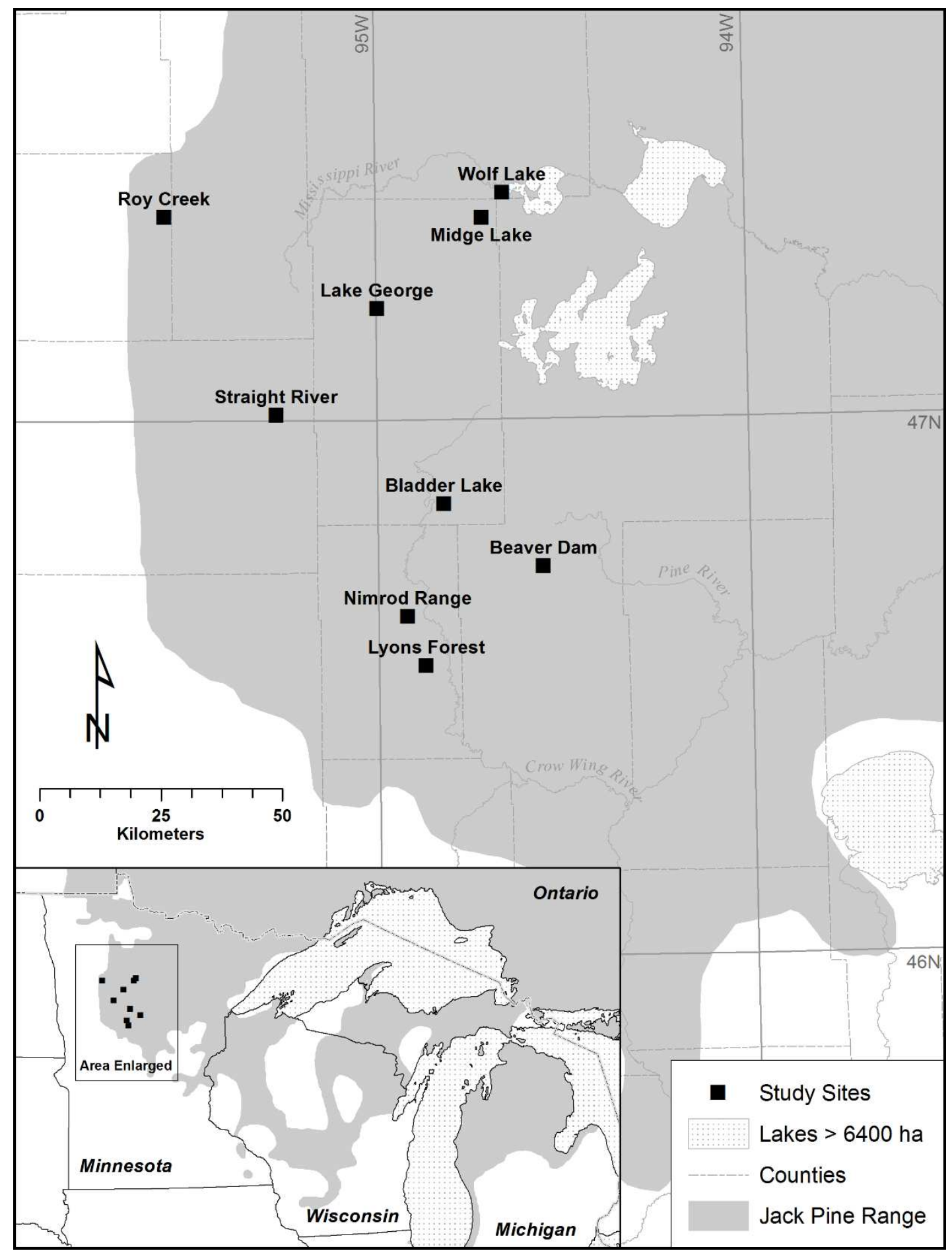


Figure 2.

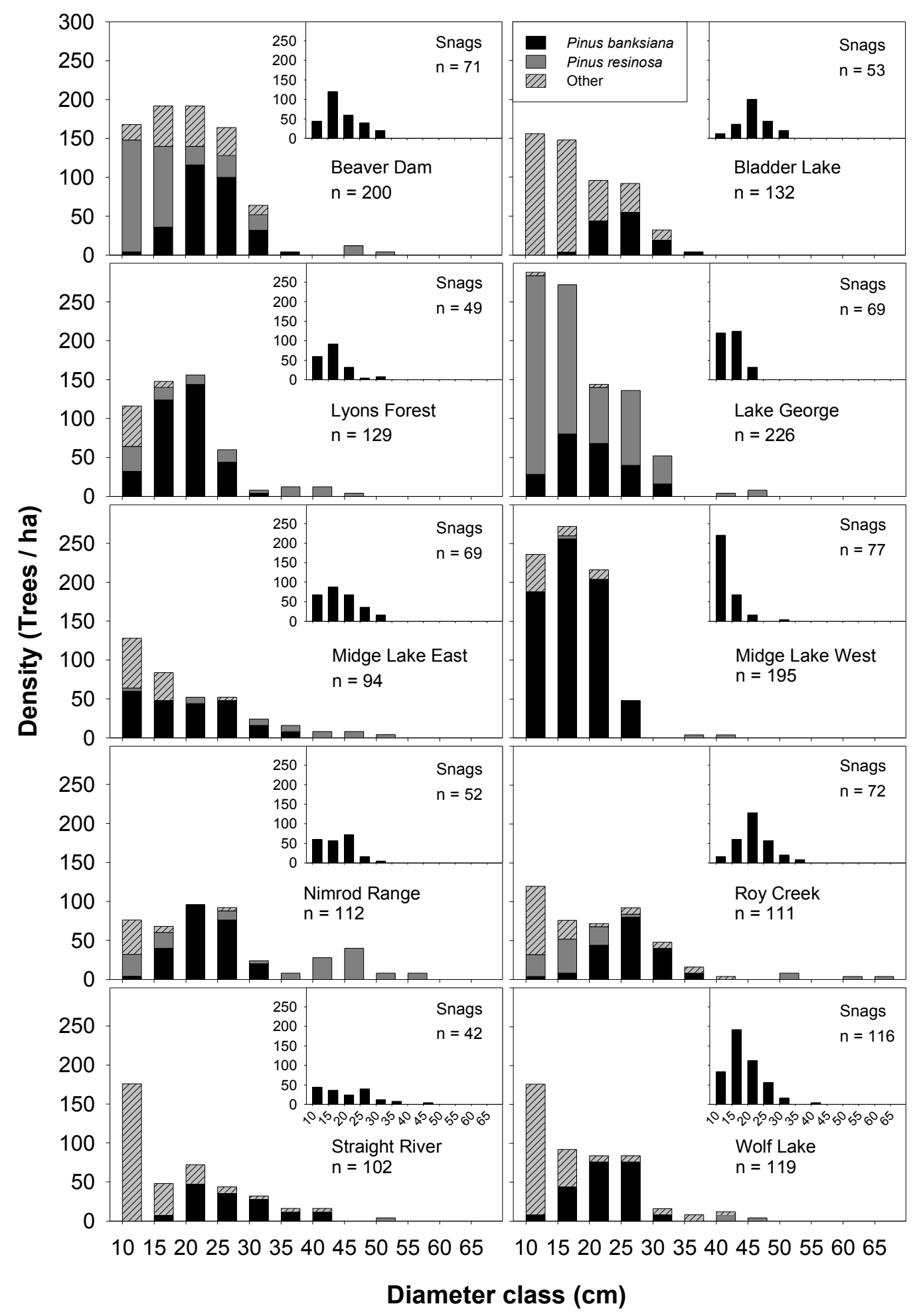


Figure 3.

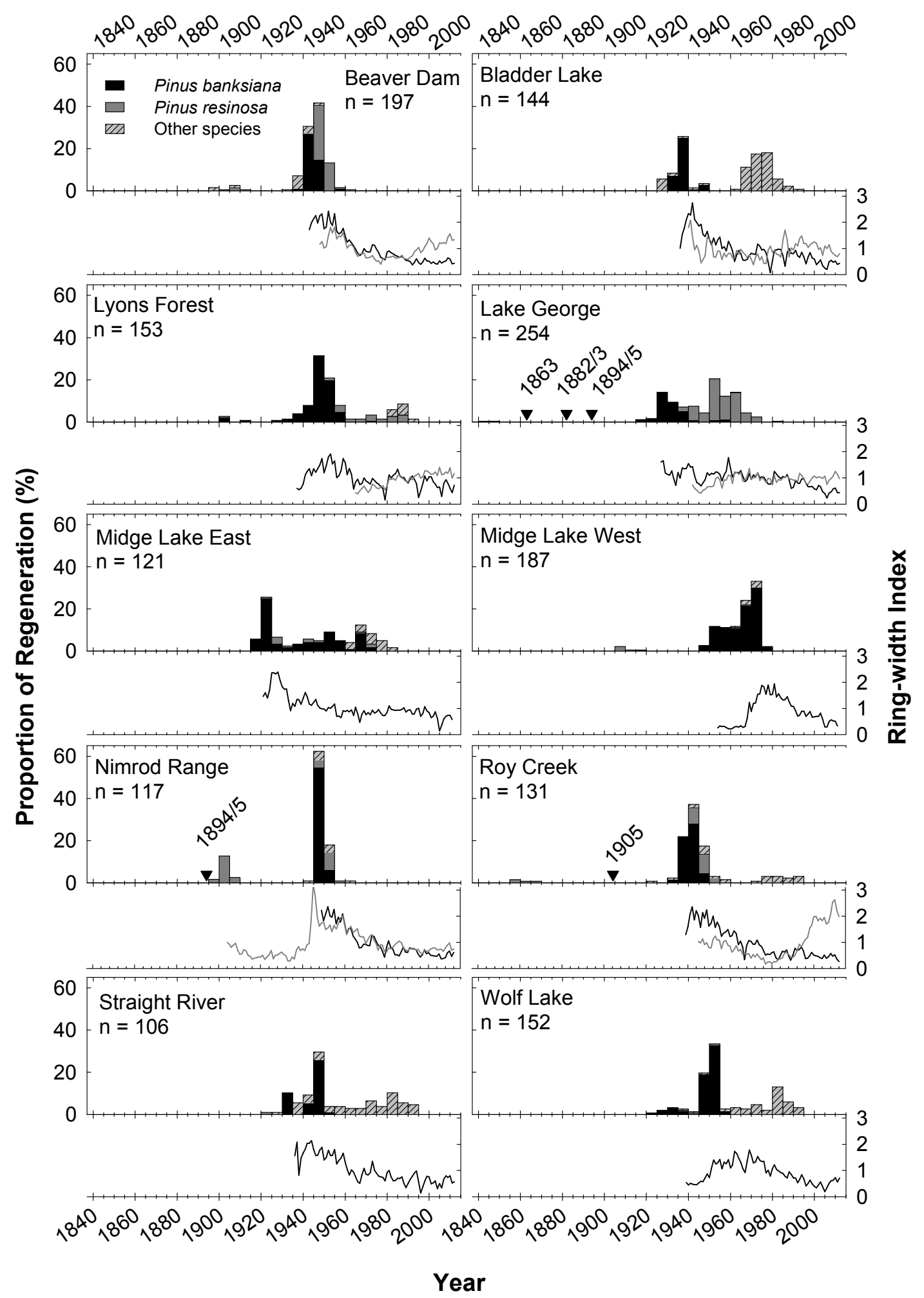




\section{Figure 4.}

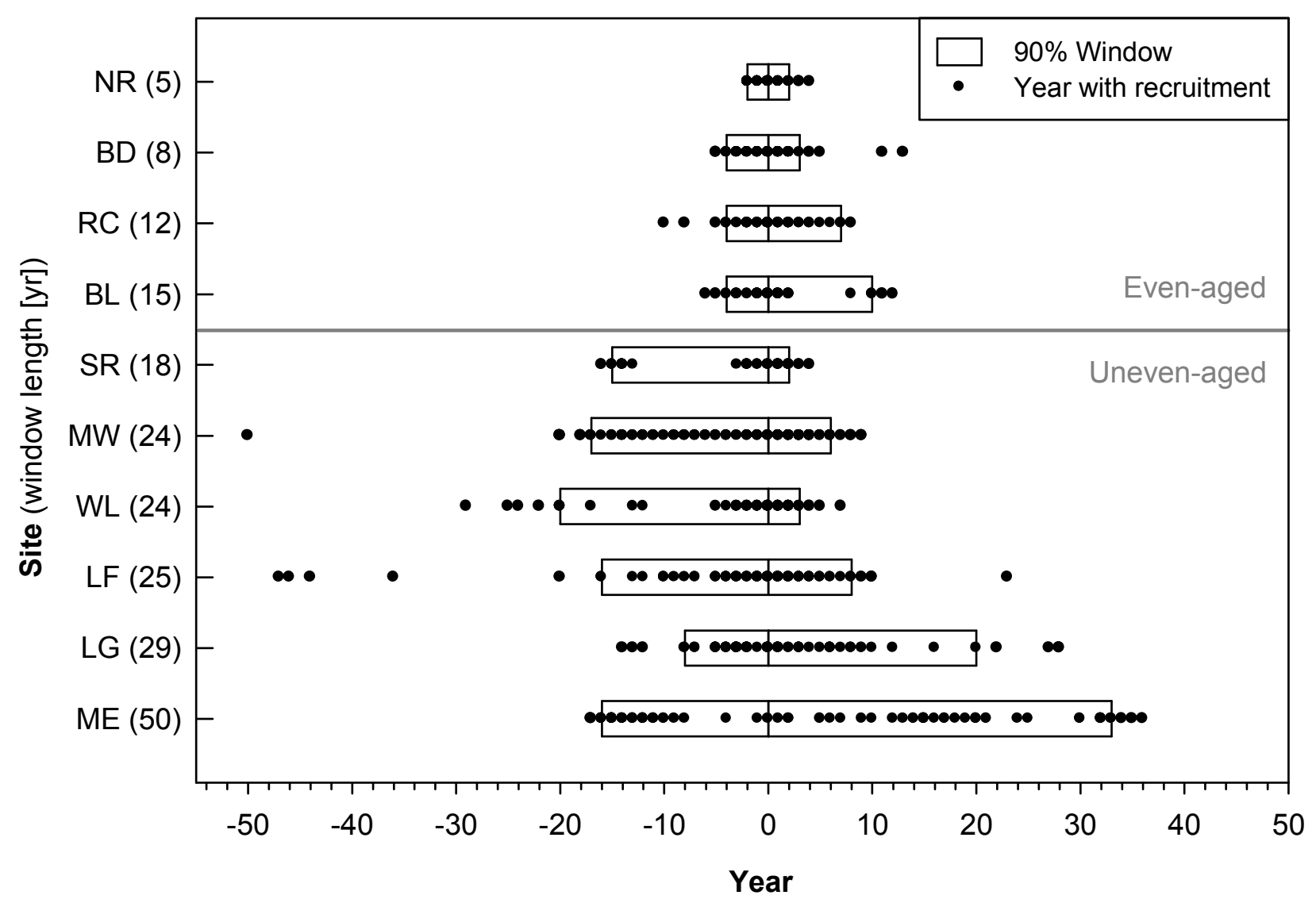




\section{Figure 5.}

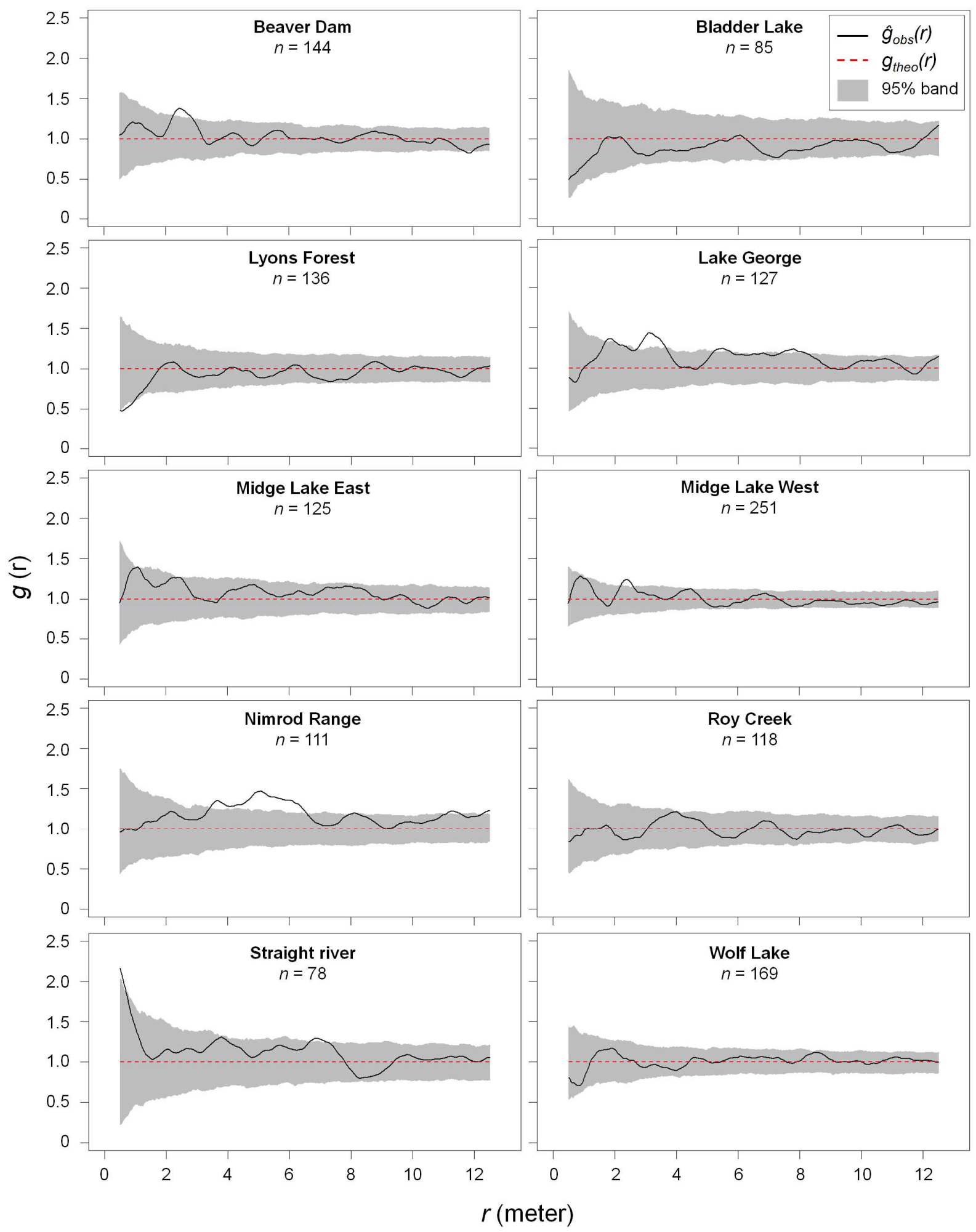


Figure 6.

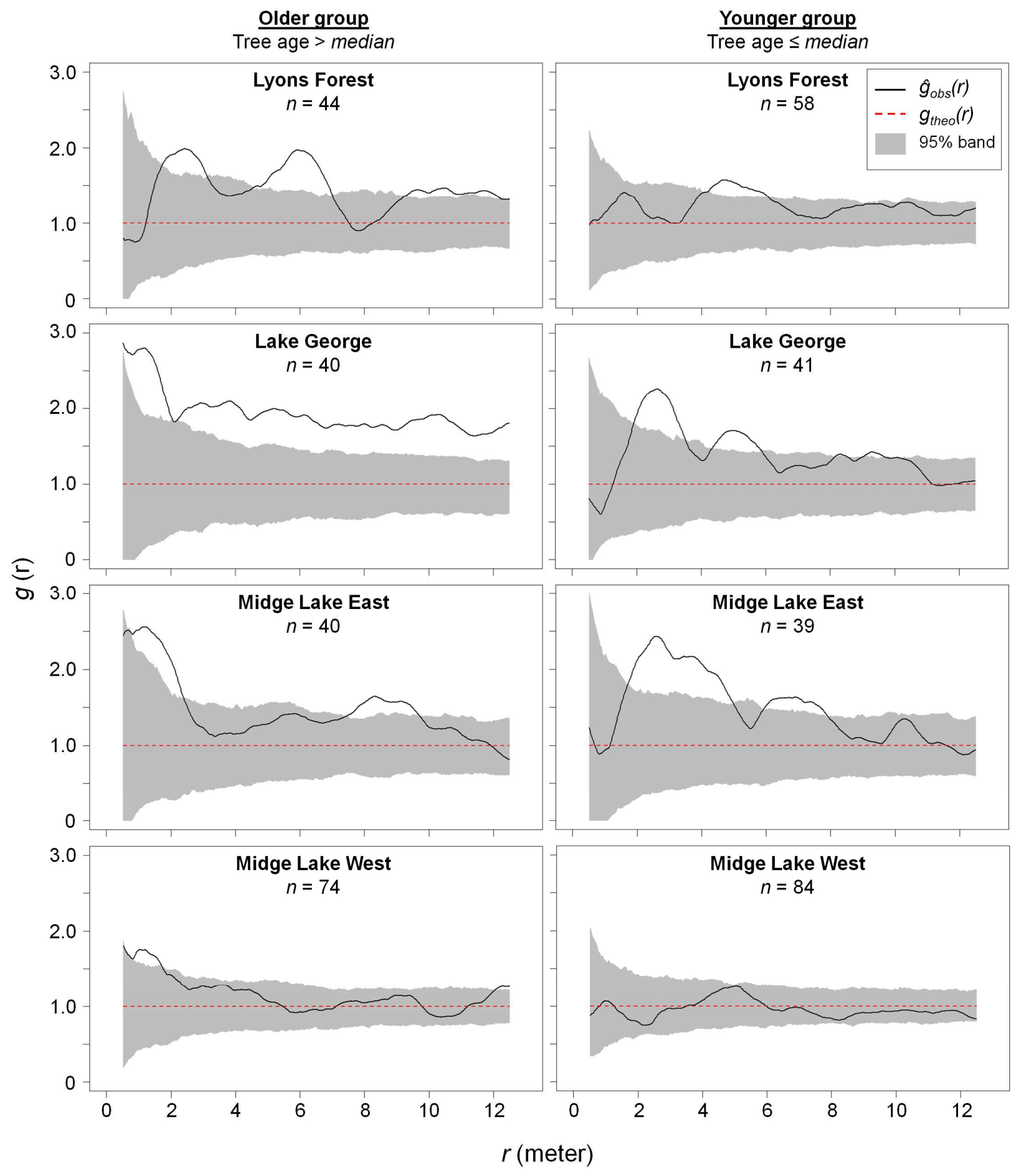

39 
Figure 7.
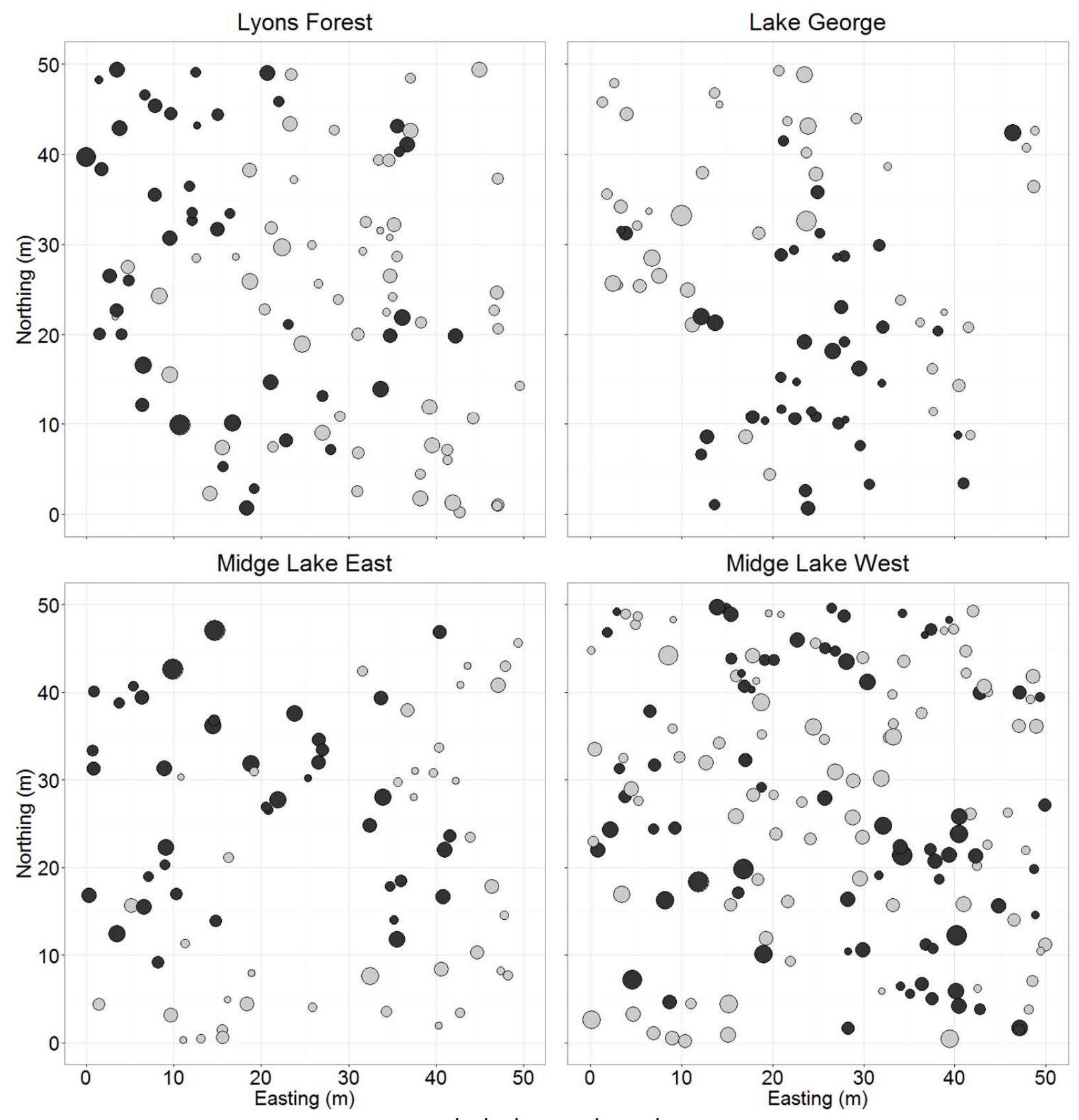

Jack pine age legend

- >median $\geq$ 


\section{Figure 8.}

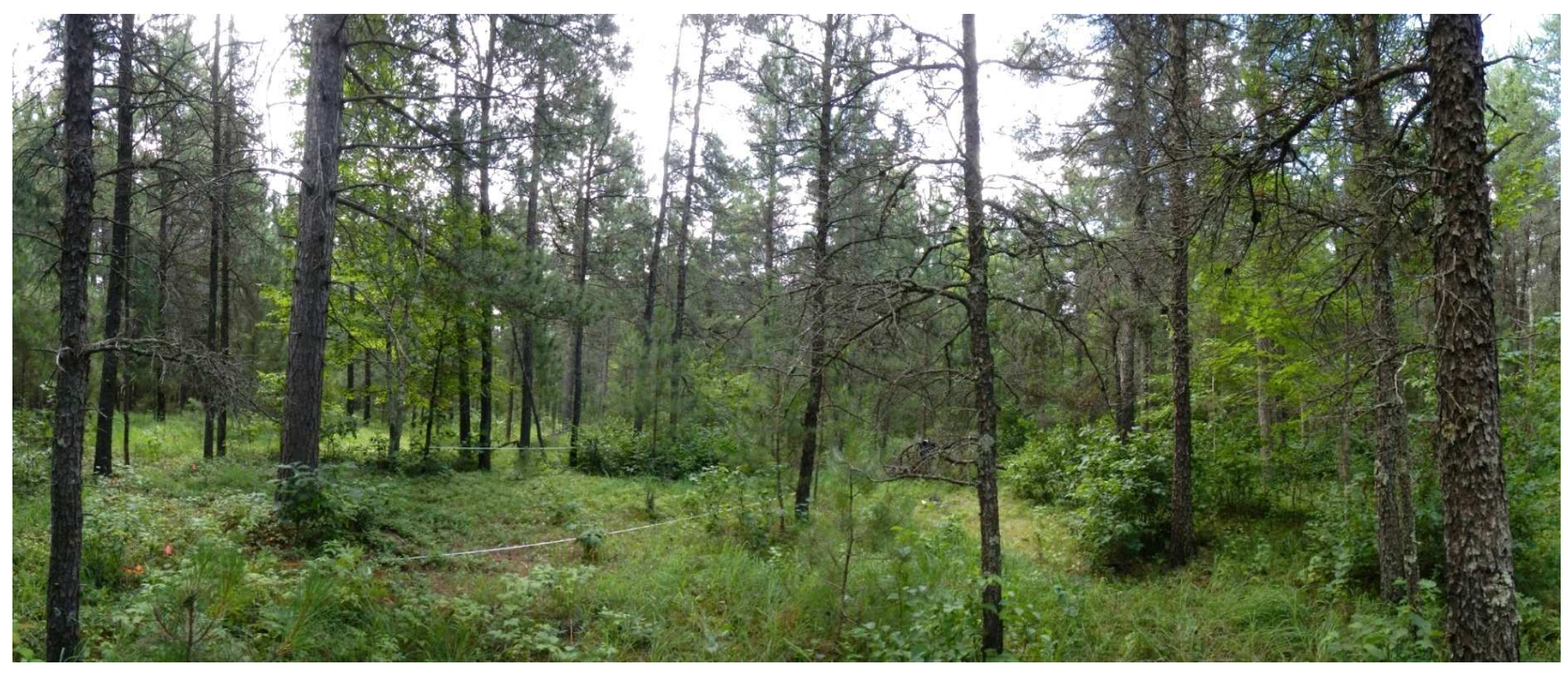




\section{Appendix}

Figure A1. Percent volume distribution of downed woody debris (DWD, $N=456$ intersections) per decay class at each range-margin jack pine site. See Table 1 (in the text) for full site names and Table 2 (in the text) for total volume at each site.

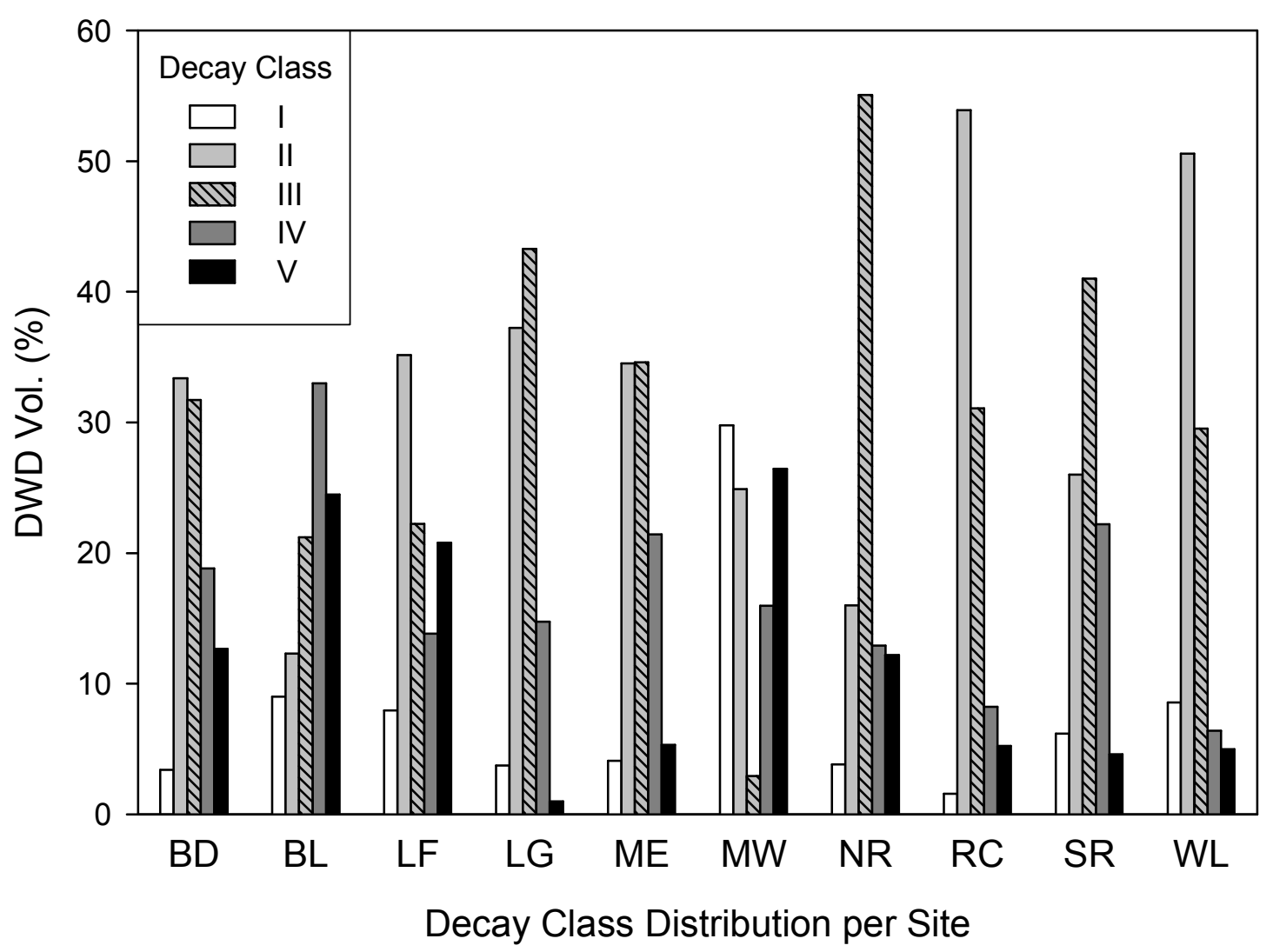




\section{Appendix.}

Figure A2. Tree locations at Nimrod Range showing even-aged jack pine trees (black circles) spatially aggregated between red pines (grey squares), most of which were around 50 years old at the time of jack pine recruitment (see Fig. 3 in the text). Jack pine stems were clumped at distances between 3.5 and $7 \mathrm{~m}$ (see Fig. 5 in the text), and red pine stems were clumped at distances between 1 and $3 \mathrm{~m}$ (results not shown). The icons are sized to reflect relative DBH; see Fig. 2 in the text for DBH distribution.

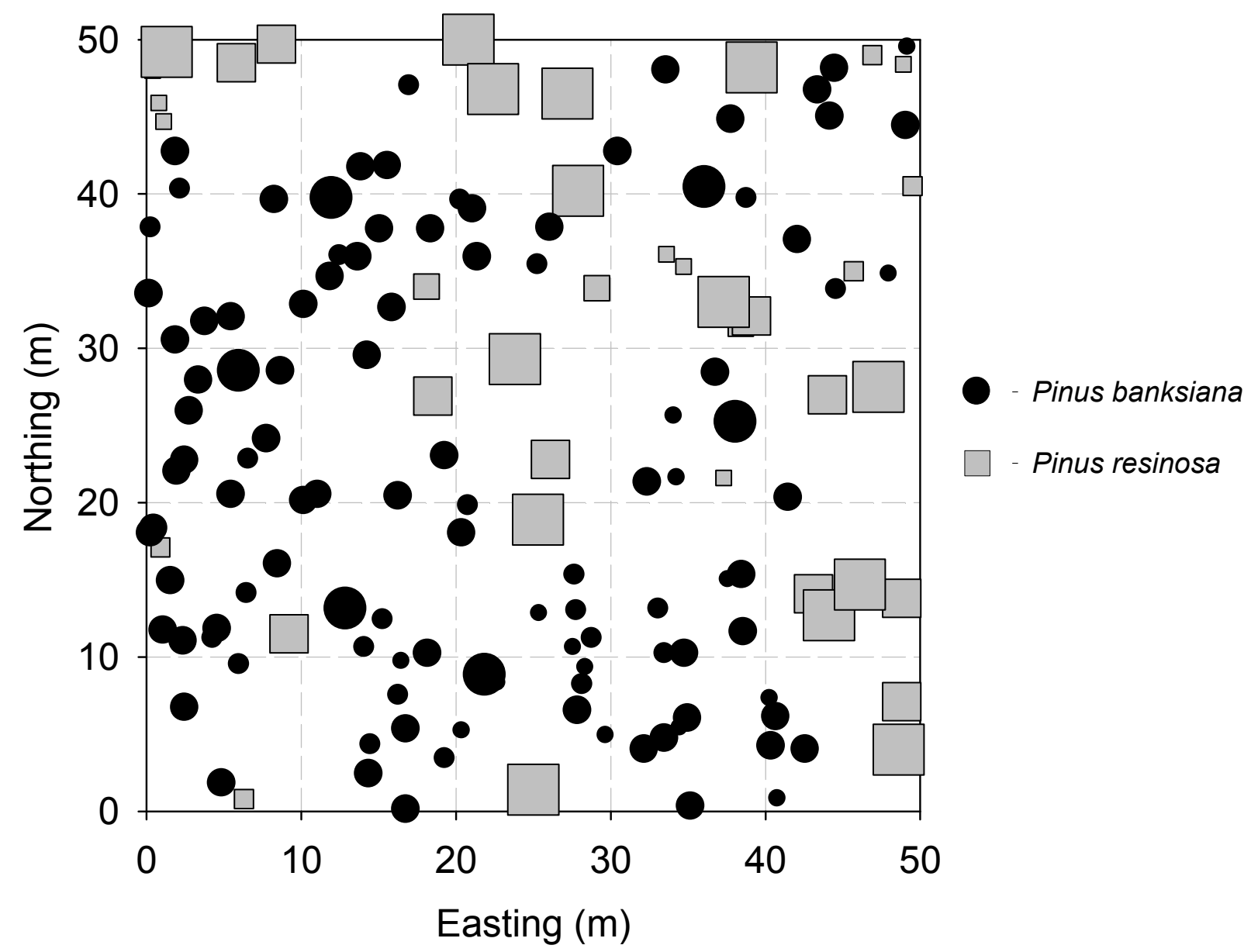

